\title{
Survival on Renal Replacement Therapy: Data from the EDTA Registry
}

\author{
F. P. Brunner \\ Departement für Innere Medizin, \\ Universität Basel, Switzerland \\ $\begin{array}{ll}\text { M. Broyer Hôpital Necker Enfanits Malades, Paris, } & \\ \text { France }\end{array}$ \\ H. Brynger \\ Department of Surgery I, Sahlgrenska \\ Sjukhuset, Göteborg, Sweden \\ S. Challah \\ St Thomas' Hospital, London, United \\ Kingdom \\ S. R. Dykes \\ St Thomas' Hospital, London, United \\ Kingdom
}

\author{
W. Fassbinder
}

Klinikum der Johann Wolfgang

Goethe-Universität, Frankfurt am Main, Federal Republic of Germany

R. Oulès

G. Rizzoni

Centre Hospitalier Regional et Universitaire de Nimes, France

Ospedale Pediatrico Bambino

Gesu, Istituto Scientifico di

Ricerca, Roma, Italy

N. H. Selwood UK Transplant Service, Bristol, United Kingdom

A. J. Wing
St Thomas' Hospital, London, United Kingdom

\begin{abstract}
Extensive survival data are presented from the EDTA Registry's files for patients who started renal replacement therapy in 1970-1974 compared to 1980-1984. The contribution of the different treatment modalities (haemodialysis, continuous peritoneal dialysis, and transplantation) to the survival of patients according to geographical region is also shown. Survival on renal replacement therapy, irrespective of treatment modality and of primary renal disease, was best in the 10-14-yearold patients, with $58 \%$ at 10 years and $52 \%$ at 15 years, and decreased with rising age to $28 \%$ at 10 years and $16 \%$ at 15 years in patients aged 45-54 when they commenced therapy in 1970-1974. When comparing the 0-4-year-old with the 10-14-year-old cohort of the paediatric patients, 5 -year survival rates for patients starting renal replace-
\end{abstract}

Correspondence and offprint requests to: Prof. F. P. Brunner. European Dialysis and Transplant Association Registry. St Thomas' Hospital. London SEI 7EH. UK. ment therapy in the early eighties declined from $85 \%$ to $70 \%$ with decreasing age.

Treatment policy, as reflected by the proportion of patients on different modes of therapy, varied markedly between European regions but affected survival to a small extent only. The large population with diabetic nephropathy incurred annual mortality rates 2-3 times greater than those observed in patients with 'standard' primary renal diseases. Haemodialysis and continuous peritoneal dialysis, although not comparable because of important differences in selection policy, yielded similar survival rates.

Patient and graft survival rates have improved markedly when comparing patients starting renal replacement therapy in the early seventies with the eighties; particularly for cadaveric transplantation. Patient survival after second grafting was similar to that after first grafting, with $83 \%$ at 5 years after second cadaveric grafting in the $15-44$-year-old cohort, vs $85 \%$ after first 
cadaver transplantation in 1980-1984. Second cadaveric graft survival was superior to average first-graft survival for those recipients whose first graft had been functioning for more than 1 year. However, second-graft survival in rapid rejectors of a first graft as well as third cadaveric graft survival were curtailed by the large number of early losses, with only $52 \%$ of third grafts functioning at 1 year. For living related donor transplantation, parents were mostly used in children whilst identical siblings predominated in adults older than 45 . In the early eighties, patient survival was $92 \%$ at 5 years for recipients younger than $15.87 \%$ for the $15-45$ year old cohort and $72 \%$ for those aged 45 or older. From the overall survival rates on renal replacement therapy obtained at 5 years in the early eighties, it appears safe to predict that at least $65 \%$ of young adults and $25 \%$ of patients aged 55-64 will be surviving at 10 years after starting therapy.

Key words: EDTA Registry; Diabetic nephropathy; Graft survival; Patient survival after renal transplantation: Regraft survival; Survival on CAPD; survival on haemodialysis; Survival on renal replacement therapy

\section{Introduction}

The EDTA Registration Committee has been asked by many members of EDTA-ERA to provide comprehensive survival data for patients on renal replacement therapy in Europe. Particular interest is anticipated. on the one hand for survival achieved in recent years, and on the other hand for long-term survival beyond 10 years. It seemed appropriate. therefore. to present survival data for patients starting treatment during the first 5 years of the last decade (1970-1974) and compare them to the cohort starting from 1980 to 1984 . Factors that might affect survival such as age and primary renal disease are also taken into account. Finally, the contribution of different methods of treatment to the survival on renal replacement therapy is examined in relation to age of patients at start of treatment and its wide variation between geographical regions.

\section{Methods}

The methods of data collection used by the EDTA Registry have been described previously [1]. This report is based on data provided on individual patient questionnaires and relates to treatment up to 31 December 1985. Patient and graft survival estimates were calculated using the actuarial method, and calculations to define the proportional contributions of the various treatment modalities to renal replacement therapy and patient survival were carried out by the methodology developed by Dr. Neville Selwood and previously described [2].

\section{Survival After First Renal Replacement Therapy}

Survival on renal replacement therapy has improved markedly in one decade. This is readily apparent for all age groups up to 65 shown in Table 1 and to a lesser extent also for the group aged over 65 at start of treatment. However, the survival figures given in Table 1 for patients over 65 may not usefully be compared, as the large difference in the numbers of patients in this group for the two periods studied was due to a substantial number of 70-80-year-olds beginning renal replacement therapy in 1980-1984. It is possible that the more liberal intake of older patients in recent years has also included an increasing number of high-risk candidates. It is no surprise that survival on renal replacement therapy still does not approach survival rates of the general population which, according to official statistics from many European countries, show an annual mortality of some $0.05 \%$ for children aged $5-14$ years, of $0.1 \%-0.2 \%$ for young adults aged between 15 and 45 years, of $0.3 \%-0.8 \%$ for the $45-54$ age cohort and of $0.7 \%-1.0 \%$ for females and $1.5 \%-2.0 \%$ for males aged $55-64[3]$.

Annual mortality on renal replacement therapy decreased with length of time on therapy, which is demonstrated in a semilogarithmic plot (Fig. 1) by an upturn in the survival curves [4]. This was more apparent in the younger as compared to the older cohorts. and also in those starting treatment in the early seventies as compared to those starting in the early eighties. That annual mortality decreased with time on renal replacement therapy is also shown in Fig. 2 for the three large age cohorts starting treatment in 1970-1974. Annual mortality decreased from $13.5 \%$ during the first year of therapy to $2 \%-3 \%$ at $10-15$ years in the $15-34$-year-old cohort. from $16 \%$ to $5 \%-7.5 \%$ in those aged $35-44$ at start of therapy, and from $17 \%$ to $10 \%-11 \%$ in the $45-54$-year-old group. Decreasing mortality with time is encouraging. since rising age is. in general, associated with a steady increase in mortality.

Most likely explanations for this finding include the more rapid drop-out of high-risk patients, such as young patients with diabetes mellitus, higher transplantation rates in the early years on renal replacement therapy with increased mortality in the first few months after transplantation, and improving quality of treatment in the course of the last $10-15$ years. Figure 3 suggests that improving quality of renal replacement therapy is unlikely to be the sole explanation. This compares the interval mortality of two age cohorts. Those patients who commenced renal replacement therapy in 1980-1984 (shown 
Table I. Paticnt survival dfter first renal replacement therapy. according to age at start of treatment. Results are given according to year of first renal replacement therapy (RRT). Number of patients at risk at time zero $(n)$ is shown. An asterisk $\left(^{*}\right)$ denotes less than 30 patients at risk

\begin{tabular}{|c|c|c|c|c|c|c|c|c|c|c|c|c|c|c|}
\hline \multirow{4}{*}{$\begin{array}{l}\text { Age at } \\
\text { first } \\
\text { RRT } \\
\text { (ycars) }\end{array}$} & \multicolumn{14}{|c|}{ Year of first renal replacement therapy } \\
\hline & \multicolumn{6}{|c|}{$1980-1984$} & \multicolumn{8}{|c|}{$1970-1974$} \\
\hline & \multirow[t]{2}{*}{$n$} & \multicolumn{5}{|c|}{$\%$ Survival } & \multirow[t]{2}{*}{$n$} & \multicolumn{7}{|c|}{$\%$ Survival } \\
\hline & & $1 \mathrm{yr}$ & $2 \mathrm{yr}$ & $3 \mathrm{yr}$ & $4 \mathrm{yr}$ & $5 \mathrm{yr}$ & & $2 \mathrm{yr}$ & $4 \mathrm{yr}$ & $6 \mathrm{yr}$ & $8 \mathrm{yr}$ & $10 \mathrm{yr}$ & $12 \mathrm{yr}$ & $15 \mathrm{yr}$ \\
\hline $0-4$ & 297 & 86 & 80 & 75 & 73 & 70 & 34 & 59 & * & * & * & * & - & * \\
\hline $5-9$ & 676 & 91 & 87 & 85 & 82 & 82 & 182 & 70 & 55 & 47 & 44 & 43 & 41 & $\bullet$ \\
\hline $10-14$ & 1404 & 96 & 91 & 89 & 87 & 85 & 570 & 80 & 72 & 66 & 61 & 58 & 57 & 52 \\
\hline $15-34$ & 18972 & 93 & 88 & 85 & 82 & 80 & 9404 & 78 & 68 & 62 & 58 & 54 & 51 & 48 \\
\hline $35-44$ & 15048 & 91 & 84 & 79 & 74 & 70 & 7073 & 73 & 59 & 51 & 45 & 41 & 35 & 28 \\
\hline $45-54$ & 21866 & 90 & 81 & 74 & 67 & 61 & 7160 & 71 & 54 & 44 & 35 & 28 & 23 & 16 \\
\hline $55-64$ & 21885 & 86 & 74 & 65 & 57 & 49 & 3251 & 64 & 43 & 30 & 21 & 14 & 10 & $*$ \\
\hline$\geqslant 65$ & 16562 & 78 & 61 & 49 & 39 & 31 & 584 & 56 & 33 & 20 & 12 & 7 & 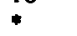 & * \\
\hline
\end{tabular}

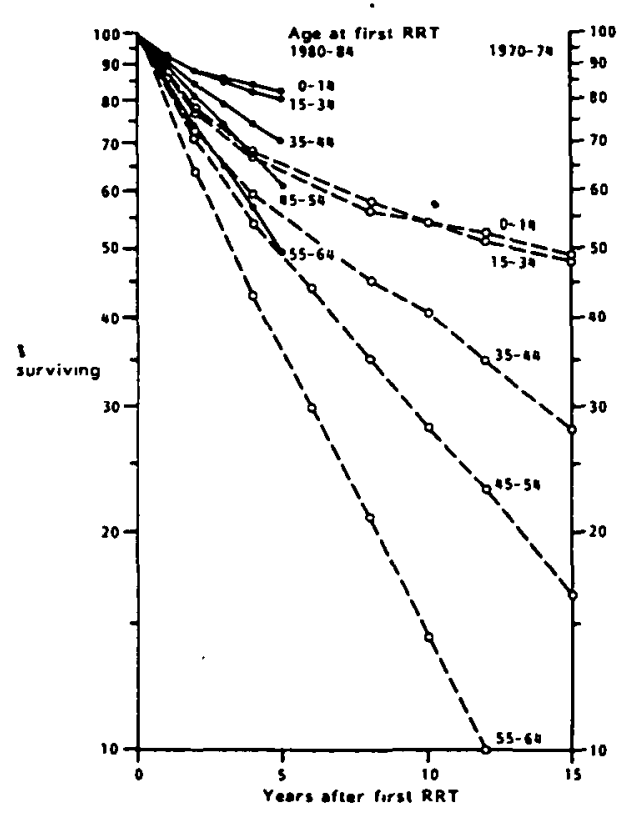

Fig. 1. Patient survival after first renal replacement therapy according to age group and year at start of treatment.

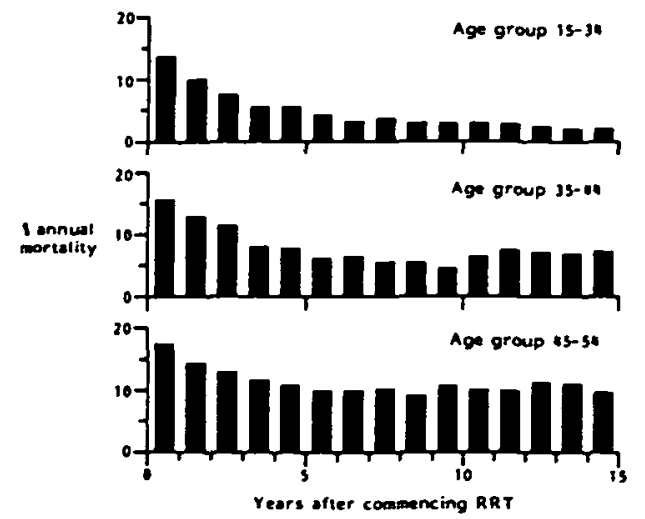

Fig. 2. Annual mortality after first renal replacement therapy (RRT) 1970-1974. according to age group. in the left panel) had higher annual mortality rates than their counterparts of the same age who had spent 10 additional years on treatment (right panel). Although interval mortality was decreasing less with time in the cohort commencing treatment in 1980-1984, it would seem safe to predict that survival at 10 years for patients who commenced renal replacement therapy in 1980-1984 would be going to exceed $72 \%$ (i.e. $85 \%$ of $85 \%$, Table 1 and Fig. 1) for the paediatric cohort aged 10-14 years and $25 \%$ (i.e. $50 \%$ of $50 \%$ ) for the $55-64$-year-old cohort.

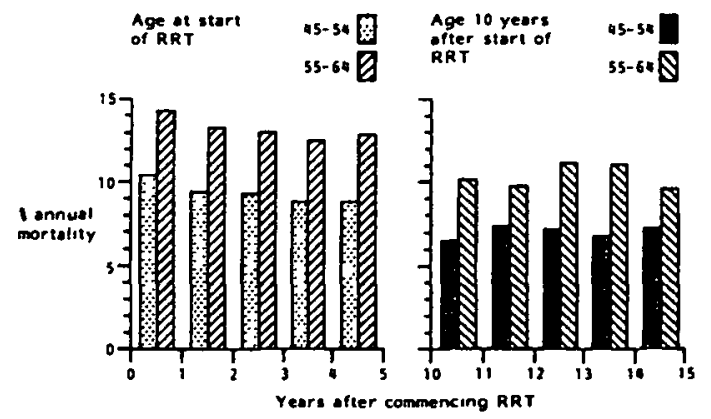

Fig. 3. Annual mortality on renal replacement therapy (RRT) 1980-1985. according to age group.

\section{Survival on Renal Replacement Therapy in Different Regions of Europe}

In order to compare geographical differences in the approach to renal replacement therapy, six groups of countries were studied. The proportional use of different methods of therapy were similar within each of the groups. Comparison between these groups of countries should highlight different survival trends on the European scene. Patient survival figures computed for these geographical regions (Table 2) can be regarded as a summary of the results of national programmes. (National 
Table 2. Patient survival after first renal replacement therapy (RRT), according to age at start of treatment in six regions of Europe

\begin{tabular}{|c|c|c|c|c|c|c|c|c|c|c|c|c|}
\hline \multirow{4}{*}{$\begin{array}{l}\text { Age at } \\
\text { first } \\
\text { RRT } \\
\text { (years) }\end{array}$} & \multicolumn{12}{|c|}{ Year of first renal replacement therapy } \\
\hline & \multicolumn{6}{|c|}{$1980-1984$} & \multicolumn{6}{|c|}{$1970-1974$} \\
\hline & \multirow[t]{2}{*}{$n$} & \multicolumn{5}{|c|}{$\%$ Survival } & \multirow[t]{2}{*}{$n$} & \multicolumn{5}{|c|}{$\%$ Survival } \\
\hline & & $1 \mathrm{yr}$ & $2 \mathrm{yr}$ & $3 \mathrm{yr}$ & $4 \mathrm{yr}$ & $5 y t$ & & $2 \mathrm{yr}$ & $4 \mathrm{yr}$ & $6 \mathrm{yr}$ & $8 \mathrm{yr}$ & $10 \mathrm{yr}$ \\
\hline \multicolumn{13}{|c|}{ Latin (France. Jtaly. Portugal, Spain) } \\
\hline $0-14$ & 867 & 95 & 91 & 89 & 87 & 85 & 286 & 80 & 71 & 64 & 60 & 58 \\
\hline $15-44$ & 10113 & 97 & 93 & 91 & 88 & 85 & 5510 & 84 & 74 & 68 & 63 & 59 \\
\hline $45-64$ & 15505 & 92 & 84 & 76 & 70 & 64 & 3672 & 78 & 60 & 48 & 39 & 31 \\
\hline$\geqslant 65$ & 6798 & 81 & 64 & 52 & 41 & 33 & 272 & 63 & 38 & 23 & 16 & 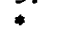 \\
\hline \multicolumn{13}{|c|}{ Benelux (Belgium. Luxembourg, Netherlands) } \\
\hline $0-14$ & 149 & 95 & 91 & 89 & 87 & 85 & 65 & 82 & 80 & 75 & 75 & 75 \\
\hline $15-44$ & 1395 & 95 & 92 & 89 & 86 & 83 & 1143 & 81 & 72 & 64 & 60 & 55 \\
\hline $45-64$ & 2348 & 88 & 79 & 70 & 62 & 55 & 911 & 79 & 60 & 47 & 36 & 26 \\
\hline$\geqslant 65$ & 1145 & 78 & 63 & so & 38 & 30 & 40 & 68 & $*$ & $*$ & * & $*$ \\
\hline \multicolumn{13}{|c|}{ British Isles (United Kingdom. Ireland) } \\
\hline $0-14$ & 359 & 93 & 91 & 87 & 85 & 85 & 144 & 77 & 62 & 57 & 51 & 47 \\
\hline 15.44 & 3649 & 94 & 89 & 86 & 83 & 80 & 2473 & 77 & 65 & 58 & 53 & 49 \\
\hline $45-64$ & 3830 & 84 & 73 & 65 & 57 & so & 956 & 65 & 48 & 38 & 30 & 23 \\
\hline$\geqslant 65$ & 609 & 69 & 53 & 44 & 33 & 20 & 7 & 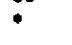 & $*$ & $*$ & * & $*$ \\
\hline \multicolumn{13}{|c|}{ Federal Republic of Germany. Austria } \\
\hline $0-14$ & 285 & 95 & 94 & 93 & 92 & 92 & 134 & 75 & 65 & 60 & 55 & 52 \\
\hline $15-44$ & 5072 & 95 & 89 & 85 & 82 & 80 & 3215 & 74 & 62 & 55 & 50 & 46 \\
\hline $45-64$ & 8886 & 88 & 78 & 69 & 61 & 54 & 2300 & 64 & 47 & 36 & 28 & 21 \\
\hline$\geqslant 65$ & 3877 & 79 & 61 & 49 & 40 & 32 & 145 & 54 & 32 & 19 & $*$ & * \\
\hline \multicolumn{13}{|c|}{ Nordic (Denmark. Finland. Iceland. Norway. Sweden) } \\
\hline $0-14$ & 93 & 93 & 90 & 88 & 85 & * & 53 & 81 & 74 & 70 & 64 & 62 \\
\hline $15-44$ & 1609 & 88 & 81 & 76 & 72 & 69 & 1078 & 70 & 57 & 51 & 47 & 44 \\
\hline $45-64$ & 2080 & 79 & 67 & 56 & 50 & 44 & 1210 & 54 & 38 & 27 & 22 & 17 \\
\hline$\geqslant 65$ & 849 & 66 & 48 & 35 & 28 & 21 & so & $*$ & * & 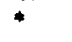 & 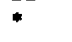 & $*$ \\
\hline \multicolumn{13}{|c|}{ Eastern (Bulgaria. Czechoslovakia, GDR. Hungary, Poland) } \\
\hline 0.14 & 173 & 83 & 73 & 72 & 70 & $*$ & 34 & $*$ & - & - & * & * \\
\hline 15.44 & 3671 & 86 & 73 & 64 & 56 & 52 & 1262 & 45 & 29 & 20 & 16 & 13 \\
\hline 4564 & 2341 & 80 & 63 & 49 & 41 & 34 & 408 & 40 & 19 & 10 & 6 & * \\
\hline$\geqslant 65$ & 72 & 74 & 38 & 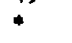 & $*$ & 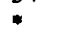 & 1 & 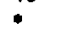 & $*$ & 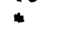 & $*$ & * \\
\hline
\end{tabular}

Number of patients at time zero $(n)$ is shown

An asterisk (*) denotes less than 30 patients at risk

survival figures were given in the Combined Report on Regular Dialysis and Transplantation in Europe, XVI, 1985, which was provided for all the renal units supplying their patient data to the EDTA Registry.) Survival rates differed little between the Latin group of countries, where the proportional contribution of transplantation has been relatively small, and the Benelux countries and the British Isles where transplantation rates have been intermediate. Lower survival was obtained in the Nordic countries with their traditionally high transplantation rates. Eastern countries showed low survival rates and the contribution of transplantation was small.

The proportional contribution of hospital (or centre) haemodialysis, home haemodialysis, intermittent peritoneal dialysis, continuous peritoneal dialysis and transplantation to patient survival in the six geographical regions is shown in Fig. 4 for the two large cohorts aged
15-44 and 45-64 years at commencement of renal replacement therapy in 1980-1984, and in Fig. 5 for patients aged 15-44 years who commenced renal replacement therapy in 1970-1974. The contribution of transplantation was larger and that of hospital haemodialysis smaller in paediatric patients of all regions, whilst the opposite, a larger contribution of hospital haemodialysis and a smaller contribution of transplantation, was observed in the older age groups than are shown in Figs 4 and 5 .

Figure 6 summarises interval mortality on all forms of treatment as well as separately on hospital haemodialysis, home haemodialysis, continuous peritoneal dialysis and with a functioning graft (primary or regraft, and all sources of donor kidney) for patients commencing treatment in the six geographical regions in 1980-1984. There were clearly marked differences between geographical regions in annual death rates (i.e. the proportion of patients at risk in 

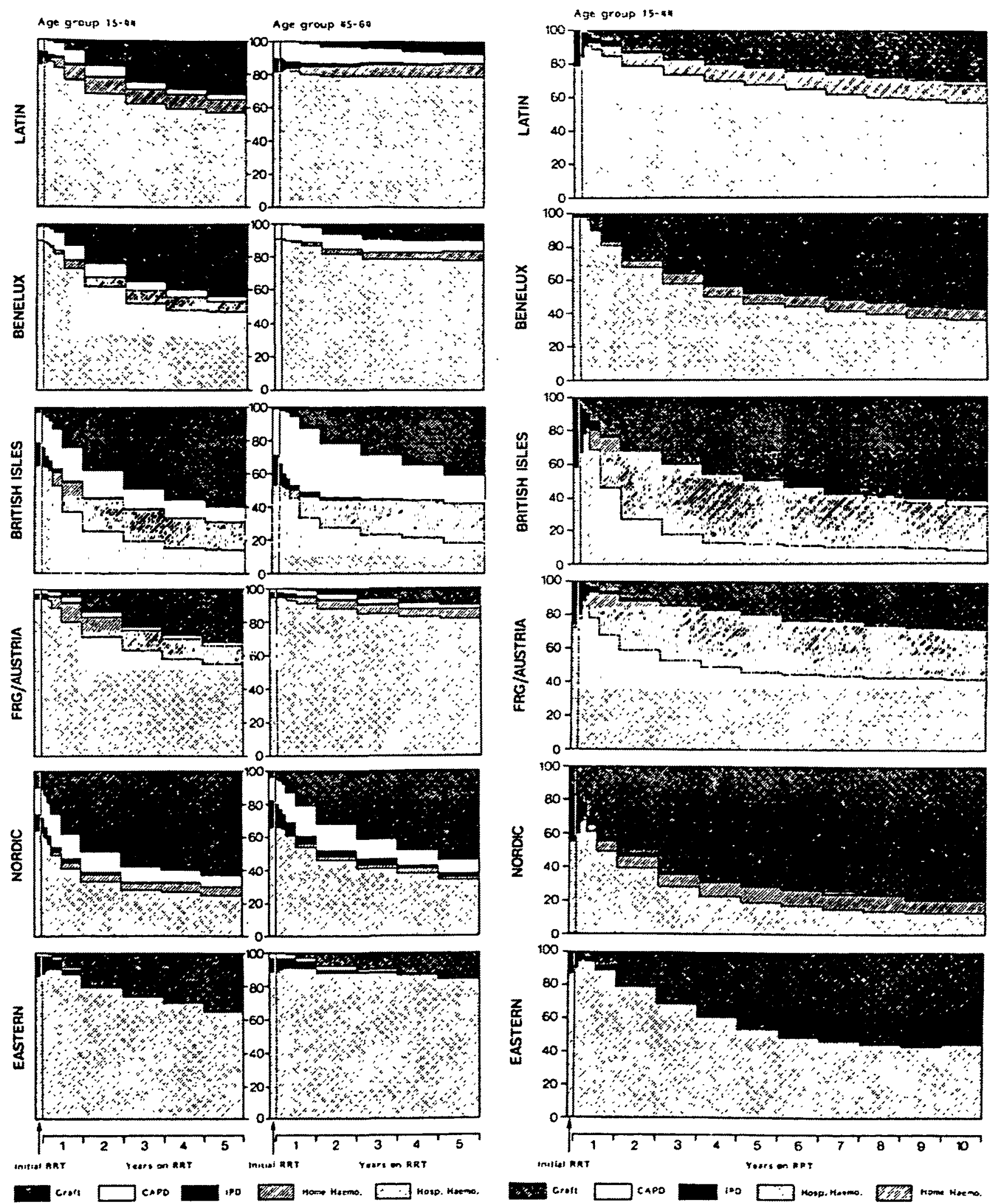

Fig. 4. Proportional contribution of different forms of renal replacement theripy at intervals after the date of starting renal replacement theraps in patients ccmmencing treatment 1980-1984, shown according to age group. Geographical regions are defined in Table 2.
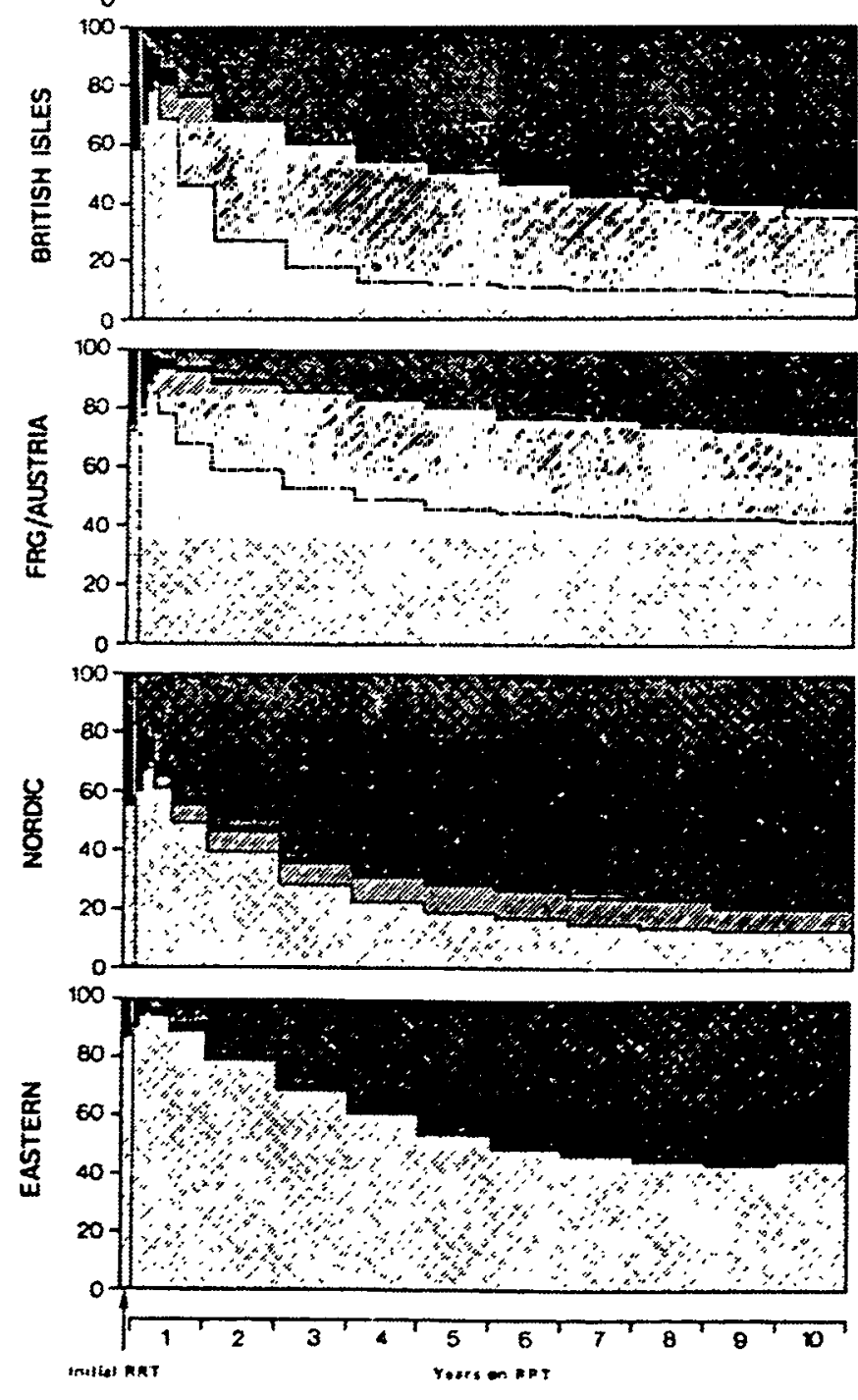

Fig. 5. Proporional coniribution of difterent forms of renal replacement therapy at intervals after the date of starting renal replacement therapy in patiens commencing treatment 1970-1974, age group 15-44 years. Geographical regions are defined in Tahle 2. 
any one year after start of renal replacement therapy who died) on specific treatment modalities. These differences appear to have resulted from differing treatment policies. The trend in the British Isles to move patients on to home haemodialysis might have generated a greater number of high-risk home-dialysis patients and thus perhaps explain the higher mortality rates in British patients as compared to residents of Latin countries. The high transplantation rates in Nordic countries can be assumed to have decreased rapidly the number of healthy long-term dialysis patients and generated a sizeable number of transplant failures who were at increased risk of dying whilst back on dialysis. The Nordic population on any form of dialysis during the third to fifth year of renal replacement therapy would thus in no way be comparable to the dialysis populations in the Federal Republic of Germany, Austria and the Latin countries.

In the course of the years, the annual death rates in patients on hospital haemodialysis changed little, and the variability in death rates on continuous peritoneal dialysis showed no regular trends. Death rates with a functioning graft were definitely at their peak during the first year of this therapy, when all grafted patients go through the early high-risk post-transplant period. Thereafter, during the second to fifth year of renal replacement therapy, death rates with a functioning graft were consistently low because patients going through the early post-transplant period after a first graft or regraft were outnumbered by far by recipients of a graft that had been functioning for a few months or longer. It should be kept in mind that complications acquired with a failing graft may ultimately cause death weeks or months later, which appear as deaths on dialysis in this type of analysis.

\section{Survival According to Primary Renal Disease}

Systemic diseases, including diabetic nephropathy, primary hypertension and malignancies which cause endstage renal failure, increase the risk of dying in comparison to the common primary renal diseases [4-9]. Separate survival rates were, therefore, calculated for patients with so-called standard primary renal diseases (chronic renal failure of uncertain aetiology, chronic glomerulonephritis, chronic pyelonephritis/interstitial nephritis, toxic nephropathies, polycystic kidney diseases), for patients with diabetic nephropathy, and for those with all other diseases including lupus erythematosus, myeloma, renal vascular diseases, etc. Mortality was confirmed to be higher in patients with systemic diseases (Table 3). This was particularly obvious in young patients with diabetes mellitus

Fig. 6. Per cent mortality in each of the first 5 years of renal replacement therapy according to method of renal replacement therapy 1980-1985. shown according to age group. Geographical regions are defined in Table 2.
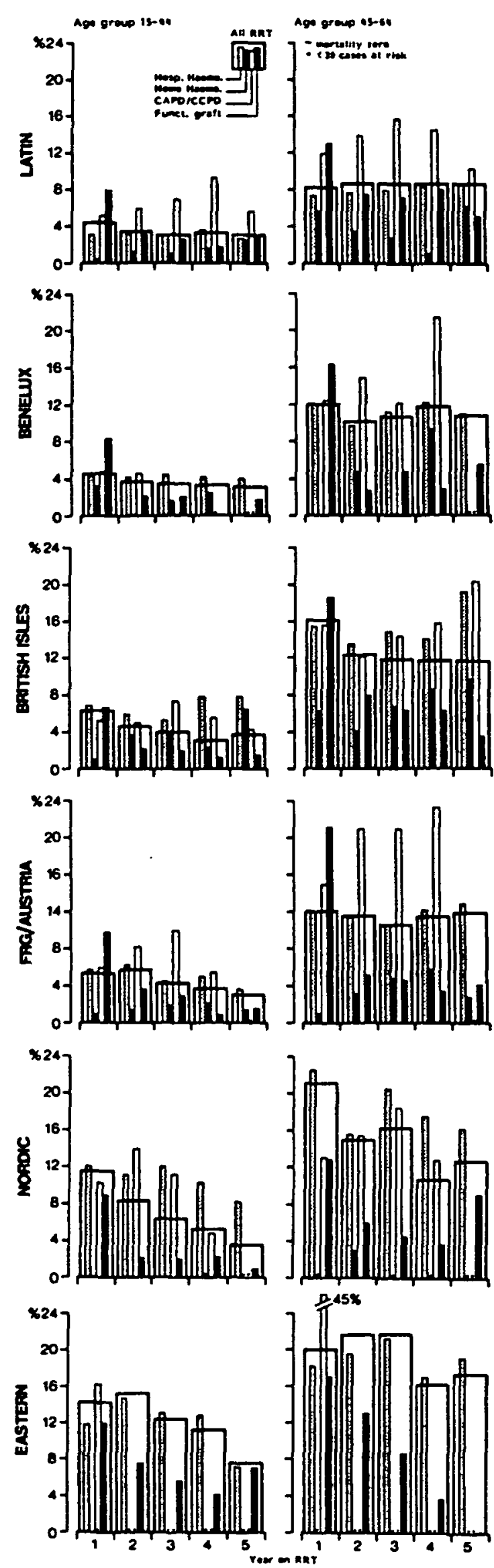
Table 3. Patient survival after first renal replacement therapy (RRT) 1980-1984 with standard primary renal disease (PRD) (which includes chronic renal failure aetiology uncertain, glomerulonephritis, pyelonephritis/ interstitial nephritis, nephropathy caused by drugs or toxic agents and cystic kidney diseases), with diabetic nephropathy and with other primary renal diseases

\begin{tabular}{|c|c|c|c|c|c|c|c|c|c|}
\hline \multirow{3}{*}{$\begin{array}{l}\text { Age at } \\
\text { frst } \\
\text { RRT } \\
\text { (years) }\end{array}$} & \multicolumn{3}{|c|}{ Standard PRD } & \multicolumn{3}{|c|}{ Diabetic nephropathy } & \multicolumn{3}{|c|}{ Other PRD } \\
\hline & \multirow[t]{2}{*}{$n$} & \multicolumn{2}{|c|}{$\%$ Survival } & \multirow[t]{2}{*}{$n$} & \multicolumn{2}{|c|}{$\%$ Survival } & \multirow[t]{2}{*}{$n$} & \multicolumn{2}{|c|}{$\%$ Survival } \\
\hline & & $2 \mathrm{yr}$ & $5 \mathrm{yr}$ & & $2 \mathrm{yr}$ & $5 \mathrm{yr}$ & & $2 \mathrm{yr}$ & $5 \mathrm{yr}$ \\
\hline $\begin{array}{l}0-14 \\
15-44 \\
45-64 \\
\geqslant 65\end{array}$ & $\begin{array}{r}1505 \\
24977 \\
31027 \\
11141\end{array}$ & $\begin{array}{l}90 \\
89 \\
82 \\
65\end{array}$ & $\begin{array}{l}83 \\
79 \\
60 \\
34\end{array}$ & $\begin{array}{l}* \\
2678 \\
3739 \\
1240\end{array}$ & $\begin{array}{l}* \\
66 \\
57 \\
42\end{array}$ & $\begin{array}{l}* \\
44 \\
25 \\
13\end{array}$ & $\begin{array}{r}818 \\
5700 \\
8344 \\
3526\end{array}$ & $\begin{array}{l}88 \\
86 \\
72 \\
55\end{array}$ & $\begin{array}{l}82 \\
75 \\
49 \\
26\end{array}$ \\
\hline
\end{tabular}

An asterisk (*) denotes less than 30 patients at risk

who succumbed at three times the rate of their counterparts with standard primary renal diseases (Fig. 7).

From this analysis of survival according to primary renal disease emerges an explanation for the lower overall survival figures obtained in Nordic countries particularly in the $15-44$-year-old cohort. There, only $53 \%$ of patients had standard primary renal diseases against almost $40 \%$ with diabetic nephropathy. As patient survival according to primary renal disease differed little between Western European regions both for standard primary renal disease and for diabetic nephropathy (Table 4), the lower overall survival results were mainly due to the high proportion of patients with diabetes mellitus among the uraemic population in Nordic countries.

\section{Survival on Haemodialysis/Haemofiltration}

In the section of the EDTA patient questionnaire which relates to treatment sequence and which is used for survival calculations, no distinction has been made between various methods of extracorporeal blood purification. We know, however, that a minority of patients have undergone haemofiltration, haemodiafiltration, or haemodialysis combined with haemoperfusion [10] and not infrequently have been changed from one of these methods to another. The majority have been treated with haemodialysis, which continues to be the most widely used mode of renal replacement therapy all over the world with the exception of the Nordic and British groups of countries, where the numbers of patients with functioning grafts exceed those on haemodialysis [10].

The figures presented in Table 5 show survival from the start of renal replacement therapy with haemodialysis/ haemofiltration. The end point of the calculation was either the date of death or the date of change to another treatment mode, i.e. peritoneal dialysis or transplantation. A change from centre to home haemodialysis/

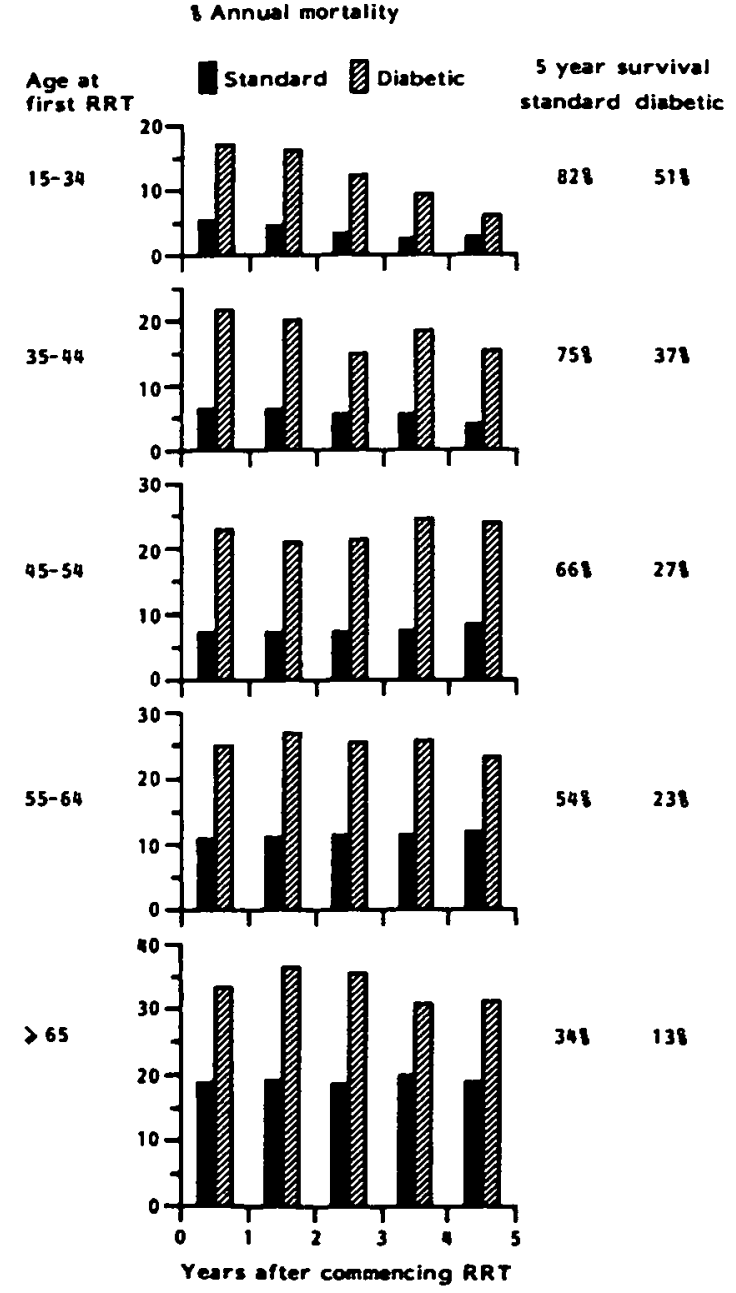

Fig. 7. Per cent annual mortality of patients with standard primary renal diseases compared to diabetics, shown according to age at first renal replacement therapy (RRT). Per cent survival at 5 years is given for each of these groups. Standard primary renal diseases are defined in Table 3.

haemofiltration was disregarded, since home treatment is not performed in some countries, and only available to a small group of more or less selected patients in many other countries. With the majority of patients with end-stage 
Table 4. Patient survival after first renal replacement therapy in 1980-1984 for patients with standard primary renal diseases (PRD) and with diabetic nephrnpathy. Results are shown according to geographical region

\begin{tabular}{|c|c|c|c|c|c|c|c|c|c|c|c|c|}
\hline \multirow[t]{4}{*}{$\begin{array}{l}\text { Geographical } \\
\text { region }\end{array}$} & \multicolumn{6}{|c|}{$\begin{array}{l}\text { Standard PRD } \\
\text { Age group }\end{array}$} & \multicolumn{6}{|c|}{$\begin{array}{l}\text { Diabetic nephropathy } \\
\text { Age group }\end{array}$} \\
\hline & \multicolumn{3}{|l|}{$15-44$} & \multicolumn{3}{|l|}{$45-64$} & \multicolumn{3}{|c|}{$15-44$} & \multicolumn{3}{|c|}{$45-64$} \\
\hline & \multirow[t]{2}{*}{$n$} & \multicolumn{2}{|c|}{$\%$ Survival } & \multirow[t]{2}{*}{$n$} & \multicolumn{2}{|c|}{$\%$ Survival } & \multirow[t]{2}{*}{$n$} & \multicolumn{2}{|c|}{$\%$ Survival } & \multirow[t]{2}{*}{$n$} & \multicolumn{2}{|c|}{ \% Survival } \\
\hline & & $2 \mathrm{yr}$ & $5 \mathrm{yr}$ & & $2 \mathrm{yr}$ & $5 \mathrm{yr}$ & & $2 \mathrm{yr}$ & $5 \mathrm{yr}$ & & $2 \mathrm{yr}$ & $5 \mathrm{yr}$ \\
\hline $\begin{array}{l}\text { Latin } \\
\text { Benelux } \\
\text { FRG/Austria } \\
\text { British Isles } \\
\text { Nordic } \\
\text { Eastern }\end{array}$ & $\begin{array}{r}8617 \\
1190 \\
4225 \\
2640 \\
859 \\
3443\end{array}$ & $\begin{array}{l}95 \\
95 \\
92 \\
93 \\
93 \\
74\end{array}$ & $\begin{array}{l}89 \\
88 \\
84 \\
84 \\
85 \\
54\end{array}$ & $\begin{array}{r}11827 \\
1729 \\
7311 \\
2574 \\
1472 \\
2114\end{array}$ & $\begin{array}{l}87 \\
85 \\
82 \\
77 \\
74 \\
65\end{array}$ & $\begin{array}{l}69 \\
64 \\
60 \\
56 \\
52 \\
36\end{array}$ & $\begin{array}{l}634 \\
147 \\
567 \\
346 \\
617 \\
138\end{array}$ & $\begin{array}{l}68 \\
75 \\
66 \\
70 \\
66 \\
38\end{array}$ & $\begin{array}{l}41 \\
46 \\
47 \\
48\end{array}$ & $\begin{array}{r}1423 \\
208 \\
1114 \\
296 \\
261 \\
100\end{array}$ & $\begin{array}{l}63 \\
52 \\
57 \\
57 \\
45 \\
30\end{array}$ & $\begin{array}{l}30 \\
24 \\
* \\
*\end{array}$ \\
\hline
\end{tabular}

An asterisk (*) denotes less than 30 patients at risk

Standard primary renal diseases are defined in Table 3

Geographical regions are defined in Table 2

Table 5. Patient survival on first haemodialysis (including home haemodialysis and haemofiltration) according to age at start of treatment. Results are given according to year of first renal replacement therapy (RRT)

\begin{tabular}{|c|c|c|c|c|c|c|c|c|c|c|c|c|c|c|}
\hline \multirow{4}{*}{$\begin{array}{l}\text { Age at } \\
\text { first } \\
\text { RRT } \\
\text { (years) }\end{array}$} & \multicolumn{14}{|c|}{ Year of first renal replacement therapy } \\
\hline & \multicolumn{6}{|c|}{$1980-1984$} & \multicolumn{8}{|c|}{$1970-1974$} \\
\hline & \multirow[t]{2}{*}{$n$} & \multicolumn{5}{|c|}{$\%$ Survival } & \multirow[t]{2}{*}{$n$} & \multicolumn{7}{|c|}{$\%$ Survival } \\
\hline & & $1 \mathrm{yr}$ & $2 \mathrm{yr}$ & 3 yr & $4 \mathrm{yr}$ & $5 \mathrm{yr}$ & & $2 \mathrm{yr}$ & $4 \mathrm{yr}$ & $6 \mathrm{yr}$ & $8 \mathrm{yr}$ & $10 \mathrm{yr}$ & $12 \mathrm{yr}$ & $15 \mathrm{yr}$ \\
\hline
\end{tabular}

Number of patients at risk at time zero $(n)$ is shown. An asterisk $\left(^{*}\right)$ denotes less than 30 patients at risk

renal disease receiving treatment by haemodialysis, it is not surprising that survival figures for any age group and at any point in time closely resemble those obtained for all forms of renal replacement therapy combined, shown in Table 1.

Figure 8 shows the lower survival rates on haemodialysis for patients with diabetic nephropathy as compared to patients with standard primary renal diseases. The difference in survival is entirely comparable to that shown for patients on renal replacement therapy in Fig. 7 or Table 3.

Lower survival rates resulting from higher annual mortality of $12.7 \%$ for $20-44$-year-old and $34 \%$ in over 65 -year-old patients on dialysis were reported from the United States for patients starting dialysis in 1977 [9]. Apart from the acceptance of more high-risk patients in the United States, this difference in the calculated survival

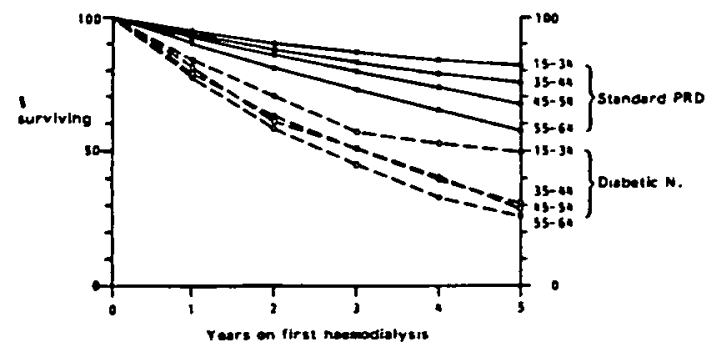

Fig. 8. Patient survival on first haemodialysis 1980-1984. standard primary renal diseases (PRD) compared to diabetic nephropathy. Standard primary renal diseases are defined in Table 3.

rates might be explained by the fact that patients who had received transplants were excluded from the analysis. This effectively removed from the analysis a part of the patient population, particularly in the younger age groups, which 
was surviving at least up to the moment of transplantation. The number of patients surviving on dialysis was thereby reduced, whilst all the deaths on dialysis were included. The European survival rates for patients on haemodialysis should, therefore, not be weighed against these American figures.

\section{Survival on Continuous Peritoneal Dialysis (CAPD/CCPD)}

Continuous peritoneal dialysis as a distinct entity was introduced as one of five methods of treatment on the EDTA Registry patient questionnaire in 1981. Accordingly. patient survival on continuous peritoneal dialysis is shown for patients starting treatment in 19811984 (Table 6). The survival rates do not differ appreciably from those obtained for patients on all forms of renal replacement therapy shown in Table 1. For several reasons these figures should not be compared to those of patients on haemodialysis. Selection of patients for either haemodialysis or CAPD is unlikely to have occurred in a randomised fashion. Local preference, availability of facilities, anticipated complications with vascular access, or diabetes mellitus may have determined whether a patient was started on CAPD rather than on haemodialysis. Conditions which might have been associated with definite differences in mortality were thus likely to show an uneven distribution between patients on CAPD as compared to haemodialysis. In fact, a much higher proportion of patients with diabetes mellitus was treated with CAPD. and the difference in survival on CAPD compared to that of patients with standard primary renal diseases (Fig. 9) was almost as striking as shown in Table 3 for any type of renal replacement therapy. Thus, taking primary renal disease into account, survival achieved by CAPD was certainly no lower, and possibly even better, than with other modes of treatment.

Table 6. Patient survival on first CAPD,CCPD. Results are shown according to age at start of renal replacement therapy in 1981-1984

\begin{tabular}{llllll}
\hline $\begin{array}{l}\text { Age at } \\
\text { first } \\
\text { RRT } \\
\text { (years) }\end{array}$ & $n$ & & \multicolumn{4}{l}{ \% Survival } \\
\cline { 3 - 6 } & & $1 \mathrm{yr}$ & $2 \mathrm{yr}$ & $3 \mathrm{yr}$ & $4 \mathrm{yr}$ \\
\hline $0-14$ & 452 & 95 & 90 & 90 & $*$ \\
$15-44$ & 3082 & 94 & 88 & 82 & 74 \\
45.64 & 5399 & 87 & 74 & 63 & 54 \\
$\geqslant 65$ & 2403 & 77 & 57 & 42 & 30 \\
\hline
\end{tabular}

An asterisk ( $\left.{ }^{*}\right)$ denotes less than 30 patients at risk

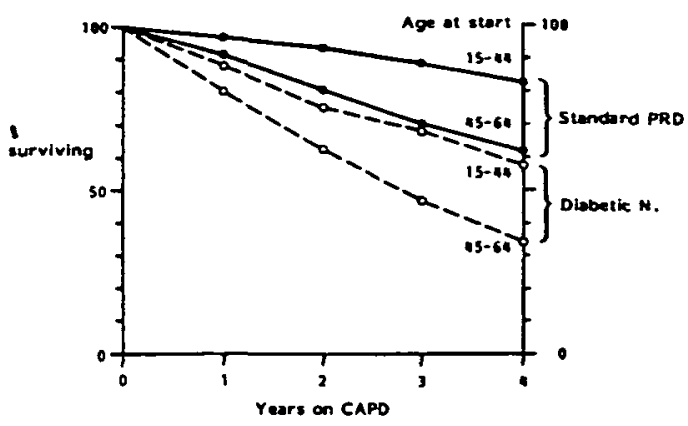

Fig. 9. Patient survival on first CAPD 1981-1984, standard primary renal diseases (PRD) compared with diabetic nephropathy. Standard primary renal diseases are defined in Table 3.

\section{Survival After Renal Transplantation}

\section{Patient and Graft Survival After First Cadaveric Graft}

The improvement in patient and graft survival rates between the early seventies and the eighties is particularly striking for cadaveric transplantation (Tables 7,8 ). This is not only due to the tremendous decline in the risk of dying during the early postoperative period, but also results from a lower interval mortality at any time after the first few post-transplant months a decade later. Figure 10 shows annual mortality after grafting, which was higher during the first year and then decreased to below 3\% interval mortality in the 15-44-year-old recipients, and to some $6 \%$ in the $45-64$-year-old cohort. This mortality involves all deaths, including also those occurring at any time after first graft failure. Taking all these deaths into account, patient survival rates in all age groups have, nevertheless, risen above those of the dialysis population as a whole. Several explanations are possible. Some lethal complications encountered in dialysed patients might no longer occur with a successful transplant, or transplantation might be performed in a physically fitter dialysis population that would have better survival despite transplantation. Whatever the explanation, it seems no longer true that the prospect of a better quality of life with a functioning transplant has to be balanced against a markedly increased risk of an early death after transplantation.

Two different ways of computing and depicting survival in transplantation are demonstrated in Fig. 11. The upper curve shows survival with a graft, i.e. only those deaths occurring whilst the graft was still functioning were considered, and all patients who survived graft failure were treated as lost to follow-up at the moment when they moved to any other mode of renal replacement therapy (or were regrafted). Interval mortalities were lower using this method for computing survival, despite the fact that the number of patients at risk becomes smaller at each interval. However, increased mortality after graft failure or during the early post-transplant period of repeated 
Table 7. Patient survival after cadaver first graft, shown according to age at grafting and year of grafting

\begin{tabular}{|c|c|c|c|c|c|c|c|c|c|c|c|c|c|c|}
\hline \multirow{4}{*}{$\begin{array}{l}\text { Age at } \\
\text { grafting } \\
\text { (years) }\end{array}$} & \multicolumn{14}{|c|}{ Year of cadaver first graft } \\
\hline & \multicolumn{6}{|c|}{$1980-1984$} & \multicolumn{8}{|c|}{$1970-1974$} \\
\hline & \multirow[t]{2}{*}{$n$} & \multicolumn{5}{|c|}{$\%$ Survival } & \multirow[t]{2}{*}{$n$} & \multicolumn{7}{|c|}{$\%$ Survival } \\
\hline & & $1 \mathrm{yr}$ & $2 \mathrm{yr}$ & $3 \mathrm{yr}$ & $4 \mathrm{yr}$ & $5 \mathrm{yr}$ & & $2 y r$ & $4 y r$ & $6 \mathrm{yr}$ & $8 \mathrm{yr}$ & $10 \mathrm{yr}$ & $12 \mathrm{yr}$ & $15 \mathrm{yr}$ \\
\hline $\begin{array}{l}0-4 \\
15-44 \\
45-64 \\
\geqslant 65\end{array}$ & $\begin{array}{r}911 \\
12794 \\
6161 \\
173\end{array}$ & $\begin{array}{l}93 \\
93 \\
86 \\
78\end{array}$ & $\begin{array}{l}91 \\
91 \\
81 \\
71\end{array}$ & $\begin{array}{l}90 \\
88 \\
77 \\
66\end{array}$ & $\begin{array}{l}88 \\
86 \\
71 \\
58\end{array}$ & $\begin{array}{l}86 \\
83 \\
67 \\
53\end{array}$ & $\begin{array}{r}191 \\
4396 \\
1837 \\
7\end{array}$ & $\begin{array}{l}79 \\
72 \\
55 \\
4\end{array}$ & $\begin{array}{l}71 \\
64 \\
45 \\
\end{array}$ & $\begin{array}{l}64 \\
58 \\
37\end{array}$ & $\begin{array}{l}59 \\
53 \\
30 \\
\end{array}$ & $\begin{array}{l}57 \\
49 \\
24 \\
\end{array}$ & $\begin{array}{l}54 \\
45 \\
21 \\
\end{array}$ & $\begin{array}{l}39 \\
15 \\
*\end{array}$ \\
\hline
\end{tabular}

An asterisk (*) denotes less than 30 patients at risk

Table 8. Survival of cadaver first grafts. shown according to age of recipient and year of grafting

\begin{tabular}{|c|c|c|c|c|c|c|c|c|c|c|c|c|c|c|}
\hline \multirow{4}{*}{$\begin{array}{l}\text { Age at } \\
\text { grafting } \\
\text { (years) }\end{array}$} & \multicolumn{14}{|c|}{ Year of cadaver first graft } \\
\hline & \multicolumn{6}{|c|}{$1980-1984$} & \multicolumn{8}{|c|}{$1970-1974$} \\
\hline & \multirow[t]{2}{*}{$n$} & \multicolumn{5}{|c|}{$\%$ Graft survival } & \multirow[t]{2}{*}{$n$} & \multicolumn{7}{|c|}{$\%$ Graft survival } \\
\hline & & $1 \mathrm{yr}$ & $2 \mathrm{yr}$ & $3 \mathrm{yr}$ & $4 \mathrm{yr}$ & $5 y r$ & & $2 \mathrm{yr}$ & $4 \mathrm{yr}$ & $6 y r$ & $8 \mathrm{yr}$ & $10 \mathrm{yr}$ & $12 \mathrm{yr}$ & $15 \mathrm{yr}$ \\
\hline $\begin{array}{l}0-14 \\
15-44 \\
45-64 \\
\geqslant 65\end{array}$ & $\begin{array}{r}908 \\
12761 \\
6150 \\
173\end{array}$ & $\begin{array}{l}69 \\
69 \\
67 \\
63\end{array}$ & $\begin{array}{l}60 \\
63 \\
61 \\
58\end{array}$ & $\begin{array}{l}54 \\
58 \\
56 \\
54\end{array}$ & $\begin{array}{l}50 \\
54 \\
50 \\
46\end{array}$ & $\begin{array}{l}44 \\
51 \\
46 \\
*\end{array}$ & $\begin{array}{r}189 \\
4385 \\
1837 \\
7\end{array}$ & $\begin{array}{l}56 \\
47 \\
39 \\
*\end{array}$ & $\begin{array}{l}48 \\
40 \\
31 \\
*\end{array}$ & $\begin{array}{l}41 \\
34 \\
26\end{array}$ & $\begin{array}{l}35 \\
31 \\
22 \\
\end{array}$ & $\begin{array}{l}29 \\
27 \\
18 \\
*\end{array}$ & $\begin{array}{l}25 \\
24 \\
15 \\
*\end{array}$ & $\begin{array}{l}* \\
20 \\
11 \\
*\end{array}$ \\
\hline
\end{tabular}

An asterisk (*) denotes less than 30 patients at risk

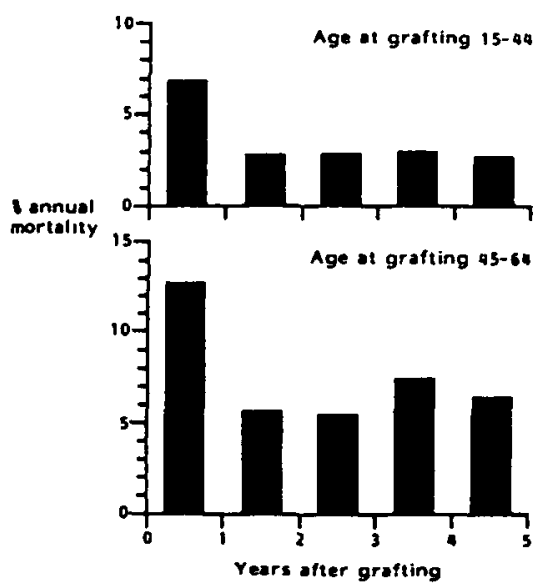

Fig. 10. Annual mortality after first cadaver graft 1980-1984, according to age at grafting.

grafting is not considered. The survival curve, therefore, has a 'better' appearance. The EDTA Registry has usually shown survival after grafting by considering all deaths occurring at any time after the event of transplantation [11]. This is depicted by the lower curve in Fig. 11, and as shown in this paper in all the Tables on patient survival after grafting.

The age dependence of survival on renal replacement therapy in general was also apparent in patient and graft survival for cadaveric transplantation performed in 1970-1974. A decade later, patient survival continued to be better in the younger compared to the older graft recipients, but the difference was less marked. Low mortality, particularly in cadaveric graft recipients older than 65 at grafting might be explained by more careful selection of low-risk candidates for transplantation in older patient groups. This may also explain why the impact of age on the first cadaveric graft survival was almost completely lost in 1980-1984. In contrast, more high-risk (including increasingly younger) paediatric patients have received grafts in more recent years. Graft survival has thus improved in all paediatric age groups, but the rising proportion of high-risk paediatric recipients aged 0-4 and 5-9 years (Fig. 12) has resulted in almost unchanged average graft survival rates for the paediatric population as a whole.

Patients with diabetic nephropathy had lower graft survival as shown in Fig. 13. The obvious reason for lower 


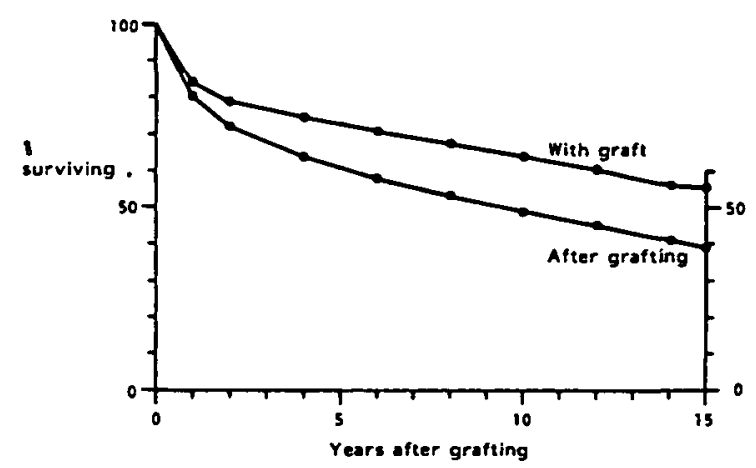

Fig. 11. Per cent patient survival, cadaver first graft 1970-1974 and age at grafting $15-44$ years.

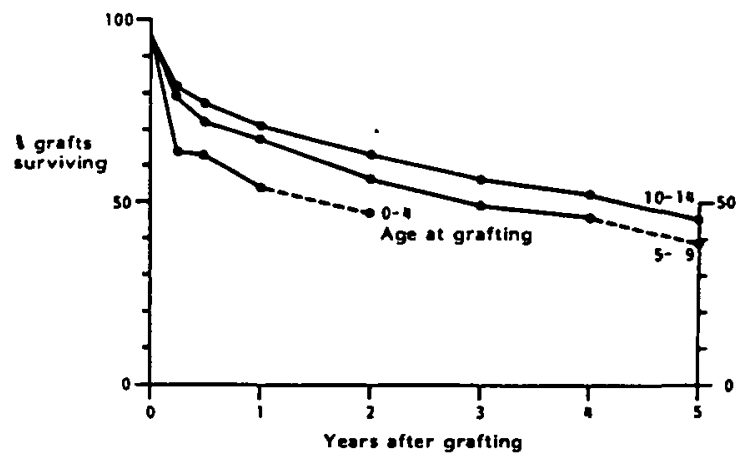

Fig. 12. Per cent cadaver first graft survival in paediatric patients 1980 1984, according to recipient age at grafting.

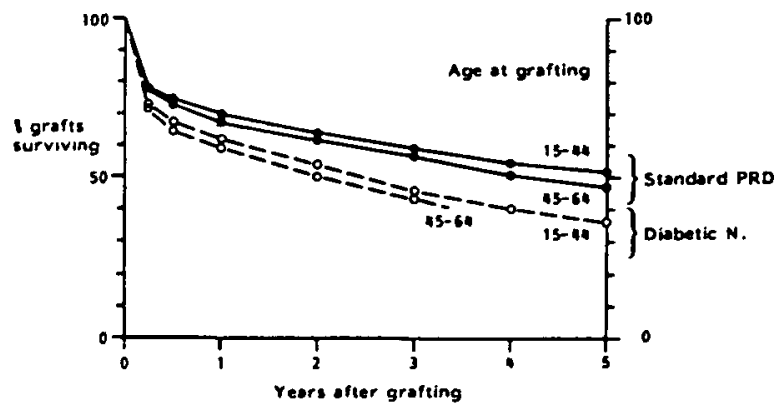

Fig. 13. Per cent first cadaver graft survival 1980-1984 according to recipient age at grafting. standard primary renal diseases (PRD) compared to diabetic nephropathy. Standard primary renal diseases are defined in Table 3.

graft survival was the markedly higher rate of death with a functioning graft which restricted survival at 5 years to $54 \%$ in the $15-44$-year-old diabetic nephropathy recipients (Fig. 14).

\section{Patient and Graft Survival After Living Related Donor First Transplantation}

Tables 9 and 10 show results obtained in patients with living related donor first grafts. The exact genetic relationship was not recorded in the early seventies but, in 1980-

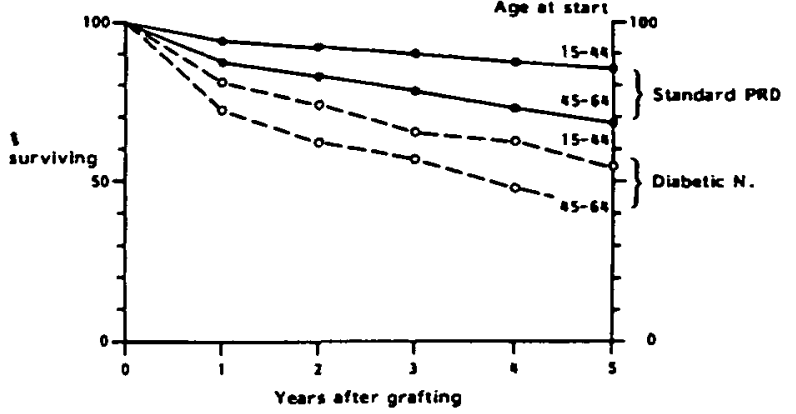

Fig. 14. Per cent patient survival after first cadaver transplant 1980-1984 according to age at start of treatment, standard primary renal diseases (PRD) compared to diabetic nephropathy. Standard primary renal diseases are defined in Table 3.

1984, the percentage of HLA-identical sibling grafts was $29 \%$, of haploidentical sibling grafts $11 \%$, and of parental grafts $58 \%$ (Table 11 ). Non-identical sibling grafts were used rarely $(1 \%)$ and genetic relationship of sibling graft donor to recipient was recorded as unknown in $1 \%$ of cases. The great majority of paediatric recipients received parental grafts, whereas almost half of the recipients aged over 45 at grafting received identical sibling grafts. Both patient and graft survival rates were superior to those obtained in cadaveric transplantation and improved during the last decade. Graft survival of haploidentical sibling and parental grafts were similar and, as was to be expected, was inferior to the graft survival of identical sibling grafts (Fig. 15).

\section{Regraft Survival}

Selection of patients by age at regrafting can be problematical with the current analytical software available for the EDTA computer. For this reason, and in order to obtain a sample of patients comparable to recipients of first grafts, age groups for second cadaveric transplantation were formed by using the year of birth. Similarly to first transplantation, results of graft and patient survival after second cadaveric transplantation have markedly improved within the last decade. The living donor second graft survival rate was much better than that obtained for cadaveric second grafts and did not differ from the living donor first graft survival rate (Tables 12 and 13).

Second cadaveric graft survival for patients aged 15-44 years at regrafting was also computed according to the fate of the first graft. One group was selected because the first graft had been lost within 6 months due to rejection, the other group because of a first-graft survival of over one year. The difference in second cadaveric graft survival between these two groups is striking. In those patients whose first graft had been functioning for more than one year, second graft survival was superior even to average first graft survival (Fig. 16). As many as $9 \%$ of second grafts in patients who had rejected the first graft within 6 
Table 9. Patient survival after live related donor first graft, shown according to age of recipient and year of grafting

\begin{tabular}{|c|c|c|c|c|c|c|c|c|c|c|c|c|c|c|}
\hline \multirow{4}{*}{$\begin{array}{l}\text { Age at } \\
\text { grafting } \\
\text { (years) }\end{array}$} & \multicolumn{14}{|c|}{ Year of live related donor first graft } \\
\hline & \multicolumn{6}{|c|}{$1980-1984$} & \multicolumn{8}{|c|}{$1970-1974$} \\
\hline & \multirow[t]{2}{*}{$n$} & \multicolumn{5}{|c|}{$\%$ Survival } & \multirow[t]{2}{*}{$n$} & \multicolumn{7}{|c|}{$\%$ Survival } \\
\hline & & $1 \mathrm{yr}$ & $2 \mathrm{yr}$ & $3 \mathrm{yr}$ & $4 \mathrm{yr}$ & $5 \mathrm{yr}$ & & $2 \mathrm{yr}$ & $4 \mathrm{yr}$ & $6 \mathrm{yr}$ & $8 \mathrm{yr}$ & $10 \mathrm{yr}$ & $12 \mathrm{yr}$ & $15 \mathrm{yr}$ \\
\hline $\begin{array}{l}0-14 \\
15-44 \\
\geqslant 45\end{array}$ & $\begin{array}{r}268 \\
1913 \\
229\end{array}$ & $\begin{array}{l}95 \\
95 \\
88\end{array}$ & $\begin{array}{l}95 \\
93 \\
83\end{array}$ & $\begin{array}{l}94 \\
91 \\
78\end{array}$ & $\begin{array}{l}92 \\
89 \\
72\end{array}$ & $\begin{array}{l}92 \\
87 \\
72\end{array}$ & $\begin{array}{r}77 \\
766 \\
88\end{array}$ & $\begin{array}{l}92 \\
85 \\
81\end{array}$ & $\begin{array}{l}82 \\
78 \\
64\end{array}$ & $\begin{array}{l}75 \\
72 \\
62\end{array}$ & $\begin{array}{l}71 \\
68 \\
53\end{array}$ & $\begin{array}{l}69 \\
65 \\
47\end{array}$ & $\begin{array}{l}69 \\
62 \\
45\end{array}$ & * \\
\hline
\end{tabular}

An asterisk $(*)$ denotes less than 30 patients at risk

Table 10. Survival of live related donor first grafts according to age of recipient and year of grafting

\begin{tabular}{|c|c|c|c|c|c|c|c|c|c|c|c|c|c|c|}
\hline \multirow{4}{*}{$\begin{array}{l}\text { Age at } \\
\text { grafting } \\
\text { (years) }\end{array}$} & \multicolumn{14}{|c|}{ Year of live related donor first graft } \\
\hline & \multicolumn{6}{|c|}{$1980-1984$} & \multicolumn{8}{|c|}{$1970 \cdot 1974$} \\
\hline & \multirow[t]{2}{*}{$n$} & \multicolumn{5}{|c|}{$\%$ Graft survival } & \multirow[t]{2}{*}{$n$} & \multicolumn{7}{|c|}{$\%$ Graft survival } \\
\hline & & $\overline{1 y r}$ & $2 \mathrm{yr}$ & $3 \mathrm{yr}$ & $4 \mathrm{yr}$ & $5 \mathrm{yr}$ & & $2 \mathrm{yr}$ & $4 \mathrm{yr}$ & $6 \mathrm{yr}$ & $8 \mathrm{yr}$ & $10 \mathrm{yr}$ & $12 \mathrm{yr}$ & $15 \mathrm{yr}$ \\
\hline $\begin{array}{l}0-14 \\
15-44 \\
\geqslant 45\end{array}$ & $\begin{array}{r}268 \\
1912 \\
229\end{array}$ & $\begin{array}{l}83 \\
82 \\
77\end{array}$ & $\begin{array}{l}78 \\
77 \\
72\end{array}$ & $\begin{array}{l}71 \\
74 \\
67\end{array}$ & $\begin{array}{l}63 \\
70 \\
62\end{array}$ & $\begin{array}{l}61 \\
66 \\
60\end{array}$ & $\begin{array}{r}77 \\
766 \\
85\end{array}$ & $\begin{array}{l}74 \\
70 \\
66\end{array}$ & $\begin{array}{l}58 \\
63 \\
56\end{array}$ & $\begin{array}{l}44 \\
56 \\
55\end{array}$ & $\begin{array}{l}39 \\
52 \\
46\end{array}$ & $\begin{array}{l}* \\
49 \\
39\end{array}$ & 43 & 37 \\
\hline
\end{tabular}

An asterisk (*) denotes less than 30 patients at risk

Table 11. Source of living related donor first graft 1980-1984

\begin{tabular}{lllll}
\hline $\begin{array}{l}\text { Age at } \\
\text { grafting } \\
\text { (years) }\end{array}$ & Percent & & & \\
\cline { 2 - 5 } & Parent & Sibling & & \\
\cline { 3 - 5 } & & ident & haplo & non? \\
\hline $0-14$ & 94 & 5 & 1 & 0 \\
$15-44$ & 58 & 29 & 10 & 3 \\
$\geqslant 45$ & 20 & 53 & 25 & 2 \\
All & 58 & 29 & 11 & 2 \\
\hline
\end{tabular}

Ident $=$ HLA identical sibling graft; haplo = haploidentical sibling graft: non/? = non-identical sibling graft, or genetic relationship of sibling graft donor to recipient recorded as unknown

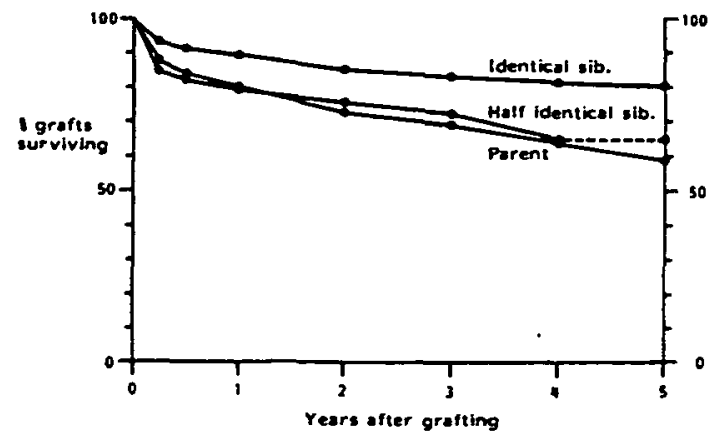

Fig. 15. Per cent live related donor first graft survival 1980-1984 for sibling and parental grafts, recipient age at grafting $15-44$ years. months never functioned, and another $27 \%$ failed within 3 months. Thereafter, no difference could be detected in the interval graft failure rates of the two groups, which was also similar to the interval failure rate of first grafts. Rapid rejectors of a first graft thus appear to lose second or subsequent grafts at a much higher rate. This same reason may explain the restricted survival of third cadaveric grafts, which nevertheless has improved in recent years (Table 14). A sizeable proportion of third cadaveric grafts never functioned, i.e. $10 \%$ of third grafts as compared to $6 \%$ on average of second grafts and $3 \%$ of first grafts performed in 1980-1984. Only 58\% of third grafts functioned up to three months, although interval graft failure rates thereafter did not appear to differ from those of first or second cadaveric grafts.

\section{Conclusions}

Despite differing treatment strategies, survival rates all over Europe were found to be similar. Transplantation has been used preferentially and for all age groups in Nordic countries, hospital or centre dialysis was the salient mode of treatment in Latin countries, and both home haemodialysis and CAPD were prominently applied in the British Isles. Survival rates improved between the seventies and the early eighties, and this was particularly 
Table 12. Patient survival after second graft according to year of grafting. Results are shown separately for patients with cadaver grafts according to age at grafting and with living related donor grafts

\begin{tabular}{|c|c|c|c|c|c|c|c|c|c|c|c|c|c|c|c|c|}
\hline \multirow{4}{*}{$\begin{array}{l}\text { Source } \\
\text { of } \\
\text { second } \\
\text { graft }\end{array}$} & \multirow{4}{*}{$\begin{array}{l}\text { Age at } \\
\text { grafting } \\
\text { (years) }\end{array}$} & \multicolumn{15}{|c|}{ Year of second grafting } \\
\hline & & \multicolumn{7}{|c|}{$1980-1984$} & \multicolumn{8}{|c|}{$1970-1974$} \\
\hline & & \multirow[t]{2}{*}{$n$} & \multirow{2}{*}{$\begin{array}{l}\text { (Year of } \\
\text { birth) }\end{array}$} & \multicolumn{5}{|c|}{$\%$ Survival } & \multirow[t]{2}{*}{$n$} & \multirow{2}{*}{$\begin{array}{l}\text { (Year of } \\
\text { birth) }\end{array}$} & \multicolumn{6}{|c|}{$\%$ Survival } \\
\hline & & & & $1 \mathrm{yr}$ & $2 \mathrm{yr}$ & $3 \mathrm{yr}$ & $4 y r$ & $5 \mathrm{yr}$ & & & $1 \mathrm{yr}$ & $2 \mathrm{yr}$ & $3 y r$ & $5 y r$ & $8 \mathrm{yr}$ & $10 \mathrm{yr}$ \\
\hline Cadaver & $\begin{array}{l}0-19 \\
15-44 \\
\geqslant 45\end{array}$ & $\begin{array}{r}205 \\
1504 \\
458\end{array}$ & $\begin{array}{l}(\geq 1965) \\
(1940-64) \\
(<1935)\end{array}$ & $\begin{array}{l}95 \\
94 \\
84\end{array}$ & $\begin{array}{l}94 \\
91 \\
76\end{array}$ & $\begin{array}{l}92 \\
89 \\
70\end{array}$ & $\begin{array}{l}88 \\
87 \\
65\end{array}$ & 85 & $\begin{array}{r}37 \\
518 \\
152\end{array}$ & $\begin{array}{l}(\geqslant 1955) \\
(1930-54) \\
(<1925)\end{array}$ & $\begin{array}{l}81 \\
77 \\
63\end{array}$ & $\begin{array}{l}78 \\
71 \\
49\end{array}$ & $\begin{array}{l}* \\
66 \\
43\end{array}$ & $\begin{array}{l}* \\
57 \\
30\end{array}$ & $\begin{array}{l}* \\
49 \\
20\end{array}$ & 45 \\
\hline $\begin{array}{l}\text { Living } \\
\text { donor }\end{array}$ & All & 139 & (any) & 96 & 90 & 88 & 88 & . & 25 & (any) & $*$ & . & . & * & * & * \\
\hline
\end{tabular}

An asterisk (*) denotes less than 30 patients at risk

Table 13. Survival of second grafts according to year of grafting. Results are shown separately for cadaver grafts according to age at grafting and for living related donor grafts

\begin{tabular}{|c|c|c|c|c|c|c|c|c|c|c|c|c|c|c|c|c|}
\hline \multirow{4}{*}{$\begin{array}{l}\text { Source } \\
\text { of } \\
\text { second } \\
\text { graft }\end{array}$} & \multirow{4}{*}{$\begin{array}{l}\text { Age at } \\
\text { grafting } \\
\text { (ycars) }\end{array}$} & \multicolumn{15}{|c|}{ Year of second grafting } \\
\hline & & \multicolumn{7}{|c|}{$1980-1984$} & \multicolumn{8}{|c|}{$1970-1974$} \\
\hline & & \multirow[t]{2}{*}{$n$} & \multirow{2}{*}{$\begin{array}{l}\text { (Year of } \\
\text { birth) }\end{array}$} & \multicolumn{5}{|c|}{$\%$ Graft Survival } & \multirow[t]{2}{*}{$n$} & \multirow{2}{*}{$\begin{array}{l}\text { (Year of } \\
\text { birth) }\end{array}$} & \multicolumn{6}{|c|}{$\%$ Graft Survival } \\
\hline & & & & $1 \mathrm{yr}$ & $2 \mathrm{yr}$ & $3 \mathrm{yr}$ & $4 y r$ & 5 yr & & & $1 \mathrm{yr}$ & $2 \mathrm{yr}$ & 3 yr & $5 y r$ & $8 \mathrm{yr}$ & $10 \mathrm{yr}$ \\
\hline Cadaver & $\begin{array}{l}0-19 \\
15-44 \\
\geqslant 45\end{array}$ & $\begin{array}{r}205 \\
1495 \\
457\end{array}$ & $\begin{array}{l}(\geqslant 1965) \\
(1940-64) \\
(<1935)\end{array}$ & $\begin{array}{l}68 \\
65 \\
54\end{array}$ & $\begin{array}{l}62 \\
59 \\
46\end{array}$ & $\begin{array}{l}51 \\
54 \\
41\end{array}$ & $\begin{array}{l}. \\
50 \\
37\end{array}$ & 47 & $\begin{array}{r}37 \\
516 \\
152\end{array}$ & $\begin{array}{l}(\geqslant 1955) \\
(1930-54) \\
(<1925)\end{array}$ & $\begin{array}{l}43 \\
49 \\
45\end{array}$ & $\begin{array}{l}* \\
41 \\
35\end{array}$ & $\begin{array}{l}38 \\
28\end{array}$ & $\begin{array}{l}* \\
31 \\
22\end{array}$ & $\begin{array}{l}* \\
24 \\
14\end{array}$ & 20 \\
\hline $\begin{array}{l}\text { Living } \\
\text { donor }\end{array}$ & All & 139 & (any) & 82 & 76 & 75 & 75 & * & 25 & (any) & * & • & * & $*$ & * & - \\
\hline
\end{tabular}

An asterisk (*) denotes less than 30 patients at risk

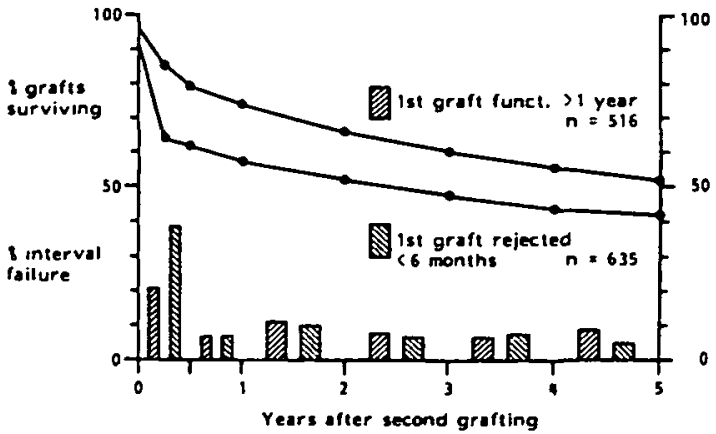

Fig. 16. Per cent second cadaver graft survival and interval failure 1980 1984. recipient age group 15-44 years and year of birth 1940-1964.

striking in transplantation. Some differences in patient survival between geographical regions might be attributed to differing treatment policies. The early post-transplant period still carries an increased risk of dying, although this has been reduced with grafts performed in recent years. The high rate of transplantation early in the course of renal replacement therapy in Nordic countries is, therefore, associated with slightly lower survival of the uraemic population during the early phase of treatment. However, the most important explanation for the higher overall mortality in Nordic as compared to Latin countries is given by the large proportion of Nordic patients with diabetic nephropathy who, particularly in the younger age groups, succumbed at a markedly higher rate than their non-diabetic counterparts.

Because of differing treatment policies or differing reasons for preferentially selecting one or another method of renal replacement therapy, one should not compare survival or mortality on different treatment modalities. All methods have their virtues and their disadvantages and may contribute equally to the survival of the uraemic population as demonstrated in the various tables shown in this paper.

Patients on renal replacement therapy are still far from approaching the survival rates of the general population which has a mortality of less than $1 \%$ annually below the age of 65 in females and 55 in males. Nevertheless, survival rates have improved in the course of the last decade and can be expected to exceed $65 \%$ for young adults and $25 \%$ for patients aged 55-64 years at 10 years after starting renal replacement therapy in the early eighties. 
Table 14. Survival of cadaver third grafts according to year of grafting

\begin{tabular}{|c|c|c|c|c|c|c|c|c|}
\hline \multicolumn{9}{|c|}{ Year of grafting } \\
\hline \multicolumn{6}{|c|}{$1980-1984$} & \multicolumn{3}{|c|}{$1970-1974$} \\
\hline \multirow[t]{2}{*}{$n$} & \multicolumn{5}{|c|}{$\%$ Graft survival } & \multirow[t]{2}{*}{$n$} & \multicolumn{2}{|c|}{$\%$ Graft survival } \\
\hline & $1 \mathrm{yr}$ & $2 \mathrm{yr}$ & $3 \mathrm{yr}$ & $4 \mathrm{yr}$ & $5 \mathrm{yr}$ & & $1 \mathrm{yr}$ & $2 \mathrm{yr}$ \\
\hline 285 & 52 & 47 & 39 & 35 & * & 71 & 41 & $*$ \\
\hline
\end{tabular}

An asterisk (*) denotes less than 30 patients at risk

Acknowledgements. The EDTA Registry is supported by grants from Governments or National Societies of Nephrology. Grants were also made by Asahi Medical Co Ltd, B. Braun Melsungen AG, Bellco S.p.A., CD Medical International Lid, Enka AG, Fresenius Ltd. Gambro AB Hospal LId, Sandoz AG, Sorin Biomedica S.p.A. and Travenol Laboratories Ltd.

We gratefully acknowledge the assistance of Mrs Ann Kaniuk in the preparation of this paper, and we would like to thank all doctors and their staff who have completed questionnaires.

\section{References}

I. Demography of dialysis and transplantation in Europe, 1984. Report from the European Dialysis and Transplant Association Registry. Nephrol Dial Transplant 1986; 1:1-8

2. Kramer $P$, Broyer $M$, Brunner $F P$ et al. Combined report on regular dialysis and transplantation in Europe, XIV, 1983. Proc Eur Dial Transplani Assoc-ERA 1985; 21: 2-68

3. WHO (1978), Demographic Year Book, Geneva

4. Wing AJ, Broyer M, Brunner FP et al. Combined report on regular dialysis and transplantation in Europe. XIII. 1982. Proc Eur Dial Transplant Assoc-ERA 1983; 20: 2-75

5. Wing AJ, Brunner FP. Brynger H, Jacobs $C$, Kramer P. Comparative review between dialysis and transplantation. In Drukker $W$, Parsons FM, Maher JF, eds. Replacement of Renal Function by Dialysis. 2nd Edition, 1983: 850-879. Martinus Nijhoff, Boston and the Hague

6. Kramer $P, B$ royer $M$, Brunner FP et al. Combined report on regular dialysis and transplantation in Europe. XII. 1981. Proc Eur Dial Transplant Assoc 1982; 19: 2-59

7. Jacobs $C$, Broyer M, Brunner FP et al. Combined report on regular dialysis and transplantation in Europe. XI. 1980. Proc Eur Dial Transplant Assoc 1981; 18: 2-58

8. Brynger $\mathrm{H}$, Brunner FP. Chantler $\mathrm{C}$ et al. Combined report on regular dialysis and transplantation in Europe, X, 1979. Proc Eur Dial Transplani Assoc 1980; 17: 2-86

9. Held PJ, Pauly MV, Diamond L. Survival analysis of patients undergoing dialysis. JAMA 1987: 257: 645-650

10. EDTA Registry centre survey, 1985. Report from the European Dialysis and Transplant Association Registry. Nephrol Dial Transplant (in press)

11. Wing AJ. Survival on integrated therapies-what assumptions shall we make? Am J Kidney Dis 1984: 4: 224-232 